\title{
Anxiety in Learning Arabic Language for the Students: A Study of Selected Two Language Centers in Dhaka, Bangladesh
}

\author{
Mahmudul Hasan ${ }^{1 *} \quad$ Syed Mahbubul Alam Al-Hasani ${ }^{2}$ \\ 1.Bachelor of Arabic Language and Literature, International Islamic University Malaysia \\ 2.Al-Madinah International University, Malaysia
}

\begin{abstract}
The aim of this present study was to find out the factors behind anxiety about learning Arabic language among the students of two language centers in Dhaka, Bangladesh. This study focused on anxiety during the learning process. A descriptive survey research design was employed for this study. A questionnaire was distributed to 150 students for collecting the required data using purposive sampling technique. Collected data were analyzed by using percentages and chi-square at 0.05 alpha levels. The results of the study found out that personal barrier, knowledge source barriers, human resource barriers and technical barriers are the reasons for the anxiety. The study concluded that anxiety has a vital effect on students' learning of Arabic language. The findings suggested some strategies in order to overcome all the anxiety-provoking barriers to learning language.
\end{abstract}

Keywords: Anxiety, chi-square, Arabic language, Learners, Personal, Barriers

DOI: $10.7176 / J L L L / 55-06$

Publication date: April $30^{\text {th }} 2019$

\section{Introduction}

In learning a new language, learners usually feel anxiety due to lack of familiarity with that language. It is a serious problem because it keeps learners away from achieving the ultimate goal. According to Masoud (2011) this anxiety first comes from the individual learners' self-related cognitions, new vocabulary memorization and the different culture associated with the new language. Anxiety in learning foreign language is one of the exciting issues that negatively affect students' perceptions when they want to learn a language. Language learning anxiety is accompanied by feelings of fear, tension, shyness and uncertainty.

Anxiety is an outcome of poor control of the language the student is trying to learn. Learners experience this problem due to linguistic difficulties in practicing the target language. However, Yahya (2013) argued that in a social context anxiety may occur due to external factors like diverse social and cultural surroundings and the atmosphere where language learning takes place.

\section{Definition of Anxiety}

Anxiety is a natural response of an individual's body to stress. Every individual has feelings of anxiety at some point in their life. For example, people feel scared and nervous on the first day of attending a new school, during job interviews, and when delivering a speech, sitting for an exam or meeting new people.

In language, anxiety refers to the experience of apprehension and nervousness in learning or using a second language. According to Gardner (1985), anxiety is a negative influence in learning language. It is one of the top grounds that influence language learning negatively.

\section{Review of the Literature}

Learning a foreign language is a cause of anxiety for most learners. Researchers identified different sources of language anxiety. Horwitz et al. (1986) recognized three language learning anxieties: communication nervousness, assessment anxiety and social evaluation. Yang (1991) introduced six aspects of anxiety, related to interpersonal connection, learner-instructor contact, beliefs of the instructor and learner about the target language, practice in the classroom and testing.

According to MacIntyre and Gardner (1994), tension is the major anxiety to learn foreign language. Gardner (1985) and Skehan (1989) stated that anxiety is the most significant cause in learning foreign languages. Firooz and Mehdi (2017) found that learners' fear of making mistakes in conversation is the most significant reason of anxiety in learning foreign languages.

There are two opinions about the nature of language anxiety. Firstly, anxiety is considered as a prime affect in the learning of a language, which comprises situational factors, involved with any situation of human life. The first is that it is just another example of the same anxiety that happens in any other situation of life. Felling scared, uncomfortable or angry can occur in any situation of practical and social life not only in learning language.

The second view is that the anxiety of learning a second language is uniquely related to the learning conditions (Horwitz et al., 1986). This anxiety is about problems faced by the students in the class while learning another language, also called "specific anxiety". These problems include students' inability to find proper words 
to express ideas due to limited vocabulary or using the wrong word or grammatical mistakes. Other examples include poor understanding of input such as listening and producing the output like conversation.

Liu (2006) studied anxiety among the language learners during their English language classes. He found that limited word-stock, minimum self-confidence, lack of practice, fear of making mistakes, grammatical error, less proficiency, pronunciation problems, poor expressive capacity etc. are the causes of language learning anxiety. Zadeh (2012) found that female students are more likely to be anxious than males because their introverted behavior made them feel shy to speak a second language. Most of the factors of Liu's study were also found in Yahya's (2013) study 104 students at the Arab American University in Palestine, Aludwil's (2014) study of 79 female EFL students in Saudi Arabia and in the study of Awan et al. (2010). In addition, cultural components are among the reasons for anxiety identified by native Cantonese speakers when learning Mandarin. As a result, the study recommended special accommodation for them to overcome this anxiety in learning the second language (Yan and Horwitz, 2008). These all are the most affective barriers, so, the questionnaire of this study was design by using these barriers to examine the anxiety and to determine the reasons for anxiety among students of two private language centers in Dhaka, Bangladesh. This was aimed at answering the following research questions.

\section{Research Questions}

In order to guide this study, the following three questions were designed:

1. What are the personal barriers responsible for anxiety when students learn the Arabic language?

2. What are the knowledge resource barriers faced by students when learning the Arabic language?

3. What are the human resource barriers responsible for anxiety when students learn the Arabic language?

4. What are the technical barriers faced by students when learning the Arabic language?

\subsection{Objectives of the Study}

The objectives of this paper are to:

1. Examine the anxiety faced by the language learners

2. Identify the anxiety faced by the language learners

3. Determine the reasons for anxiety when learning the Arabic language

4. Find out the barriers responsible for anxiety

\section{Methodology}

A descriptive survey research design is employed for this current study. A questionnaire was distributed to the targeted population for collecting the required data. The questionnaire was divided into five sections: collecting background information, asking about personal barriers, knowledge source barriers, human resource barriers and finally technical barriers. Around 150 respondents were selected from two language centers located in Dhaka, capital city of Bangladesh. These two language centers were chosen because of students' availability and easy communication. 120 respondents out of $150(80 \%)$ completed and returned the survey questionnaires. A purposive sampling technique was adopted due to the insufficient sample size. The survey questionnaires were distributed by hand to the respondents.

\subsection{Validity and Reliability of the Instrument}

For the validity of the instrument, researchers requested experts in the field for their valuable comments on the questionnaire. Three pilot questionnaires were also given to the target population, whose comments were requested on the items to know if there were any ambiguous matters or words. Thus, experts and respondents provided suggestions for improvement and the researcher identified the ambiguous terms and did the correction. For reliability of the instrument, data was subsequently subjected to a chi-square test, a result of 0.63 at alpha level of significance 0.05 was found. This indicates that the data is reliable and thus further analysis can be done.

\subsection{Data Analysis}

Collected data were analyzed through using percentages and a chi-square at 0.05 alpha levels to examine the anxiety and determine the reasons for anxiety of the respondents to the level of interest.

\section{Findings and Discussion}

Table 6. 1: interesting level of students to learn Arabic

\begin{tabular}{|l|l|l|}
\hline Level of interesting & Frequency & Percentage $\%$ \\
\hline Very good & 20 & $16.6 \%$ \\
\hline good & 75 & $62.5 \%$ \\
\hline Average & 25 & $20.8 \%$ \\
\hline Total & 120 & $100 \%$ \\
\hline
\end{tabular}


The above table shows that students are very much interested to learn this language and this level is high. This proves that less interest maybe not one of the reasons for anxiety faced by the students when learning Arabic language.

Table 6. 2: reasons for learning Arabic language

\begin{tabular}{|l|l|l|l|}
\hline Reasons of learning Arabic Language & Total Respondents 120 & Frequency & Percentage \% \\
\hline For further higher study & 120 & 118 & $98.3 \%$ \\
\hline for good result & 120 & 105 & $87.5 \%$ \\
\hline For a good job & 120 & 97 & $80.8 \%$ \\
\hline For learning new language & 120 & 88 & $73.3 \%$ \\
\hline For getting more knowledge about Islam & 120 & 89 & $74.1 \%$ \\
\hline
\end{tabular}

This indicates that majority of students learn Arabic language for further higher study, for a good result, for a good job, for new language and Islamic knowledge purpose.

Table 6. 3: Personal barriers for anxiety when learning Arabic language are fear of committing mistakes, lack of confidence, felling shy to talk, low expression ability and low English proficiency.

\begin{tabular}{|l|l|l|l|}
\hline Calculated Chi-Square Value & Critical Chi-Square Value & Degree of Freedom & Level of Significance \\
\hline 18.15 & 7.82 & 3 & 0.05 \\
\hline
\end{tabular}

Above table demonstrates that respondents' answer to the questions on personal barriers responsible for anxiety when learning Arabic language. The calculated value is higher than the critical value for 3 degree of freedom at 0.05 level of significance. Majority of respondents answered that personal barriers have an influence on anxiety. Respondents identified that fear of committing mistakes, lack of confidence, felling shy to talk, low expression ability and low English proficiency are the major causes for anxiety in learning Arabic language.

Table 6. 4: knowledge resource barriers faced by the students when learning Arabic language are limited vocabulary, poor grammatical knowledge and inappropriate pronunciation.

\begin{tabular}{|l|l|l|l|}
\hline $\begin{array}{l}\text { Calculated Chi-Square } \\
\text { Value }\end{array}$ & $\begin{array}{l}\text { Critical Chi-Square } \\
\text { Value }\end{array}$ & $\begin{array}{l}\text { Degree of } \\
\text { Freedom }\end{array}$ & $\begin{array}{l}\text { Level of } \\
\text { Significance }\end{array}$ \\
\hline 17.42 & 7.82 & 3 & 0.05 \\
\hline
\end{tabular}

This table shows responses to questions on knowledge resource barriers responsible for anxiety. A majority of respondents agreed that knowledge resource barriers are partly responsible for the language learning anxiety due to its calculated value is higher than the critical value.

Table 6. 5: Human resources barriers that responsible for anxiety when learning Arabic language are lack of management, short of IT staff and inadequate support staff.

\begin{tabular}{|l|l|l|l|}
\hline $\begin{array}{l}\text { Calculated Chi-Square } \\
\text { Value }\end{array}$ & $\begin{array}{l}\text { Critical Chi-Square } \\
\text { Value }\end{array}$ & $\begin{array}{l}\text { Degree of } \\
\text { Freedom }\end{array}$ & $\begin{array}{l}\text { Level of } \\
\text { Significance }\end{array}$ \\
\hline 15.42 & 6.82 & 3 & 0.05 \\
\hline
\end{tabular}

Above table explains that a majority of respondents experienced that human resources barrier have the influence on learning language and contributed to anxiety. Lack of management, short of IT staff and inadequate support staff are the responsible for learning anxiety since the critical value is not higher than calculated value.

Table 6. 6: Technical barriers faced by the students when learning Arabic language are slow internet connection, limited service, old computer, sort of audio-visual lab and short of learning equipment.

\begin{tabular}{|l|l|l|}
\hline Technical Barriers & Frequency & Percentage \% \\
\hline Slow internet connection & 38 & $13.4 \%$ \\
\hline Limited service & 20 & $7.1 \%$ \\
\hline old computer & 27 & $9.5 \%$ \\
\hline Sort of audio-visual lab & 9 & $3.2 \%$ \\
\hline Short of learning equipments & 20 & $7.1 \%$ \\
\hline
\end{tabular}

This table shows that technical barriers comprised of slow internet connection, limited service, old computer, sort of audio-visual lab and short of learning equipments. These all are responsible for the causes of language learning anxiety.

\section{Summary of the findings:}

This study was conducted to examine the anxiety and to determine the reasons for anxiety to learn Arabic language for the Students of selected two language centers in Dhaka, Bangladesh. Four research questions were employed to guide the study.

The findings are summarized as follows:

- Students' interest level is high, so below interest are maybe not one of the reasons for anxiety

- Majority of students learn Arabic language for the purpose of further higher study, good result, good job, learning new language and for more knowledge about Islamic.

- Majority of respondents agreed that personal barriers have major influence to anxiety, since calculated 
value is higher than critical value.

- Majority answered that knowledge resource barriers are partly responsible for the anxiety, because here also the calculated value is higher than the critical value.

- Majority of respondents experienced that human resources barriers have the influence on learning language and contributed to anxiety.

- Technical barriers are responsible for the causes of language learning anxiety, while Slow internet connection has the highest frequency with $13.4 \%$ responsibility for anxiety among the technical barriers.

\section{Conclusion and Recommendations}

The findings of the current study suggested that language anxiety can originate from problems related to learners' sense of 'self', from knowledge resources, human resources and technical resources when learning a different language. All the above-mentioned barriers have influence and responsibility for anxiety to learn the Arabic language. After reaching the conclusions stated above, the study made some recommendations for reducing the anxiety of the students about learning the Arabic language.

- Considering the anxiety of the language learners, the teacher is deemed highly important in assisting them to overcome their personal barriers to achieve the intended performance goals in the target language.

- Teachers should take effective strategies to solve learners' knowledge barriers. They should develop learner-centered strategies for their students through problem-solving activities, regular mock tests and conversation among the students, as well as reading and writing practice to correct grammatical errors (Hashem and Abbas, 2013).

- $\quad$ There is a need for a strong management team and enough IT and support staff must be available.

- The language centers must arrange alternative sources of power, e.g., solar energy, generator, or inverter and batteries.

- Authorities must provide high-speed internet, unlimited services, sufficient computer units and enough audio-visual labs and learning equipment.

\section{References}

Awan, R.N., Anwar, M.N., \& Naz, A. (2010). An investigation of foreign language classroom anxiety and its relationship with students' achievement. Journal of College Teaching \& Learning, 7 (11), 33-40.

Firooz, S. and Mehdi, D. (2017). The Sources of Foreign Language Speaking Anxiety of Iranian English Language Learners. International Journal of Education \& Literacy Studies. Volume: 5 Issues: 4. Pages 111115. Published by Australian International Academic Centre PTY.LTD.

Gardner, R. C. (1985). Social psychology and second language learning: The role of attitude and motivation. London: Edward Arnold.

Hashemi, M., \& Abbasi, M. (2013). The role of the teacher in alleviating anxiety in language classes. International Research Journal of Applied and Basic Sciences, 4(3), 640-646.

Horwitz, E. K., Horwitz, M. B., \& Cope, J. (1986). Foreign language classroom anxiety. The Modern Language journal, 70(2), 125-132.

Liu, M. (2006). Anxiety in EFL classrooms: Causes and consequences. TESL Reporter, 39(1): 13-32.

MacIntyre, P. D., \& Gardner, R. C. (1994). The subtle effects of language anxiety on cognitive processing in the second language. Language learning. Vol. 44, Issue 2. Pages 283-305.

Masoud, H. (2011). Language Stress And Anxiety Among The English Language Learners. Procedia- Social and Behavioral Sciences. Volume 30. Pages 1811-1816. doi.org/10.1016/j.sbspro.2011.10.349

Skehan, P. (1991). Individual differences in second language learning. Studies in second language acquisition. Vol. 13, Issue 2. Pages 275-298.

Yahya, M. (2013). Measuring speaking anxiety among speech communication course students at the Arab American University of Jenin (AAUJ). European Social Sciences Research Journal, 1(3), 229-248.

Yan, J.X. and Horwitz, E.K. (2008). Learners' Perceptions of how anxiety interacts with personal and instructional factors to influence their achievement in English: A qualitative analysis of EFL learners in China. Language learning 58 (1), 151-183

Zadeh, M. M. (2012). Investigating Foreign Language Speaking Anxiety within the EFL Learner's Interlanguage System: The Case of Iranian Learners. Journal of Language Teaching \& Research, 3 (3). 